I would urge reading a little further, to the chapters dealing with what the chauvinist physicist might term the less, ahem, 'fundamental' sciences. Be gripped, under the heading evolutionary biology, by the story of our "selfsacrificing ancestors", the cyanobacteria, who synthesized oxygen that we might come to live; or marvel, in the chapter on molecular biology, at the simply, utterly, madly successful construction that is the biological cell. Did you know that in every human cell, some 2,000 new proteins are created every second? That's $1.28 \times 10^{21}$ proteins in each of us each day!

$\mathrm{Ah}$, that sweet, sweet exponential notation, proud badge of our common scientific heritage (in a lovely little touch Angier dedicates her book to Rick, "my one in $\left.6.5 \times 10^{9 \prime}\right)$. Because, after all, we're all in this science game together: before we complain too much about the general public's indifference, we should make sure our own house is in order. In an age of ever more atomized specialism, a dip into The Canon is a great way to refresh our appreciation of those beautiful basics.

\section{Richard Webb}

Richard Webb is the physical sciences editor of Nature News \& Views

\title{
EXHIBITION
}

\section{The chatter of 100,000 voices}

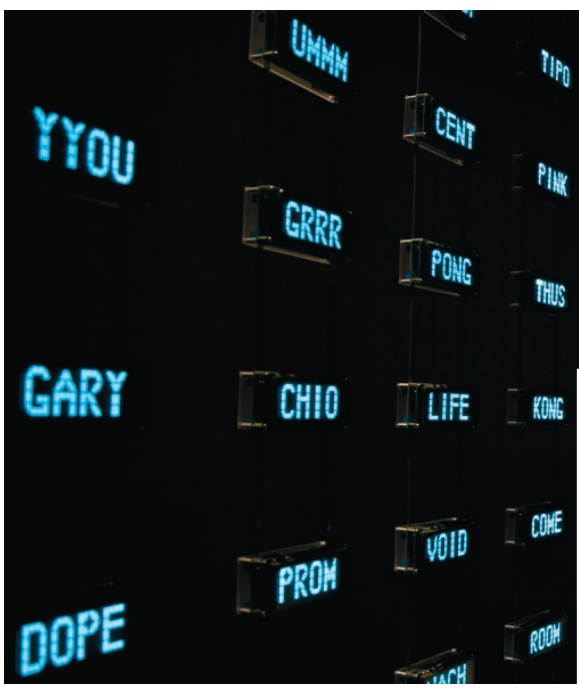

Flashing lights, computer-synthesized sound-bytes from the web, surroundsound music - is it art or technology? The installation at the Science Museum in London is both, and more. Listening Post is a collaboration between a professor of statistics, Mark Hansen, and media artist, Ben Ruben. They use a computer programme to trawl through the internet, culling words from live chatrooms, bulletin boards and so forth. The random, uncensored thoughts are processed through different filters and displayed, together with music and other sounds, on an array of two hundred small screens, through seven 'movements'.

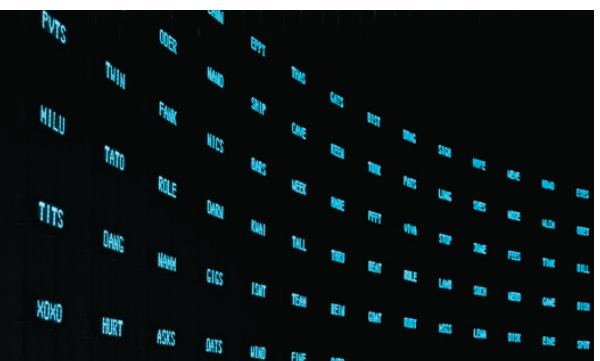

the room through eight speakers. A few movements later, "I am" came up - I am 28; I am 46; I am from Austria; I am not friggin' blind - I had gone full circle (I think).

Despite feeling overwhelmed by all the information, each bit presented with equal weighting, I started to see that it was all about connecting. Most

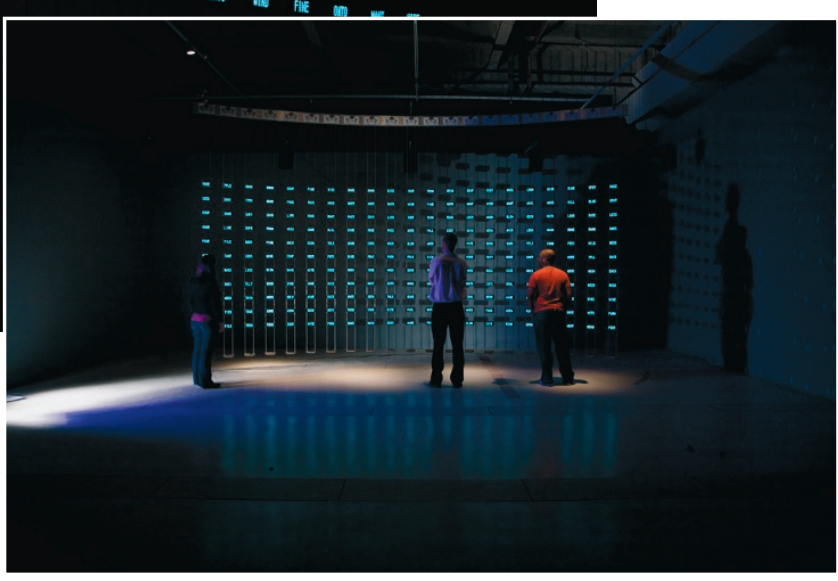

of the words were related to relationships health, money - just like 'normal', or dare I say, 'old-fashioned' conversations. These people are just reaching out. Of course, they don't know that halfway around the world I am standing there seeing their thoughts, out of context, but participating in a chatroom means that you expect an audience. My exit from the

As words scroll across the screens - usually far too fast for my visual bandwidth - I only catch the odd word. Other movements are slower and only a few screens are lit; for instance, there is the "I like" or "I love" theme: I like Pink Floyd; I like KFC chicken; I like movies; I love exs they just ruin your life; I love you to death. All the while, ambient music or keyboard tapping noises circle museum was recorded by camera on a large screen. A sign next to the camera told me that the average Londoner is snapped by 300 cameras per day. Whether we like it or not, in this technological age, we all have an audience.

The Listening Post will appear next at the Reina Sophia in Madrid.

May Chiao 